\title{
HYPOLIPIDEMIC POTENTIAL OF METHANOLIC EXTRACT OF GRACILARIA CORTICATA ON STREPTOZOTOCIN-INDUCED DIABETIC RATS
}

\author{
SEKAR SUBASHINI ${ }^{1}$, KAVASSERI GANESAN KRIPA ${ }^{2 *}$, KODUKUR VISWANATHAN PUGALENDI ${ }^{3}$ \\ ${ }^{1}$ Department of Biotechnology, School of Life Sciences, Vels University, Chennai, Tamil Nadu, India. ${ }^{2}$ Department of Biochemistry, \\ School of Life Sciences, Vels University, Chennai, Tamilnadu, India. ${ }^{3}$ Department of Biochemistry and Biotechnology, Faculty of Science, \\ Annamalai University, Annamalainagar, Tamilnadu, India Email: kgkripa.sls@velsuniv.ac.in
}

Received: 28 November 2016, Revised and Accepted: 20 December 2016

ABSTRACT

Objectives: Diabetes mellitus is associated with profound alterations in the levels of plasma lipids and the lipoprotein profile. Herbs and herbal drug preparations find wide use in alleviating the complications of uncontrolled diabetes owing to their low cost and lesser side effects. This study was aimed at establishing the hypolipidemic effect of methanolic extract of sea weed Gracilaria corticata on streptozotocin (STZ)-induced diabetic rats.

Methods: STZ-induced Wistar male albino rats were administered with methanolic extract of Gracilaria corticata (MGC) at a dosage of 100 mg/kg BW/day per orally for 45 days. Glibenclamide $(600 \mu \mathrm{g} / \mathrm{kg} \mathrm{BW} /$ day $)$ administered rats served as standard drug control. Animals were sacrificed on $46^{\text {th }}$ day, biochemical parameters associated with lipid metabolism were analyzed in blood and tissue samples, statistical significance determined.

Results: Elevated levels of total cholesterol, triglycerides, and free fatty acids were observed in the plasma and tissues of diabetic rats as compared to MGC and glibenclamide treated groups. The diabetic rats also had elevated levels of low-density lipoprotein (LDL-C) and very low-density lipoprotein (VLDL-C) and decreased levels of high-density lipoprotein (HDL-C) while the MGC and glibenclamide treated rats showed near normal levels of these indices.

Conclusion: This study establishes the hypolipidemic potential of MGC in STZ-induced diabetic rats.

Keywords: Gracilaria corticata, Diabetes mellitus, Hypolipidemic, Streptozotocin.

(C) 2017 The Authors. Published by Innovare Academic Sciences Pvt Ltd. This is an open access article under the CC BY license (http://creativecommons. org/licenses/by/4. 0/) DOI: http://dx.doi.org/10.22159/ajpcr.2017.v10i3.16373

\section{INTRODUCTION}

Diabetes mellitus is a faction of metabolic diseases characterized by hyperglycemia due to defects in insulin secretion, insulin action, or both. The chronic hyperglycemia of diabetes is linked with long-term damage, dysfunction and failure of different organs, especially the eyes, kidneys, nerves, heart, and blood vessels [1]. The predominance of diabetes is quickly rising everywhere throughout the globe at a terrifying rate. In the course of recent years, the status of diabetes has changed from being viewed as a mellow issue of the elderly to one of the main causes of morbidity and mortality influencing the adolescent and moderately aged individuals [2]. Streptozotocin (STZ) is a monofunctional glucosamine-nitrosourea compound derived from Streptomyces achromogenes and is one of the most frequently used agents to induce diabetes in experimental animals [3]. Impairments in lipid metabolism associated with Type II diabetes mellitus include abnormal lowdensity lipoprotein (LDL) metabolism, often coupled with an increased very low-density lipoprotein (VLDL) secretion and impaired VLDL catabolism. Patients with diabetic mellitus are more likely to develop microvascular and macrovascular complications than the nondiabetic population [4]. Although different types of oral hypoglycemic agents are available along with insulin for the treatment of diabetes mellitus, there is growing interest in herbal plant remedies due to the side effects associated with these therapeutic agents [5]. Diabetes mellitus has also been associated with an increased risk for developing premature atherosclerosis due to an increase in TG and LDL, and decrease in HDL levels [6]. In recent times, few medicinal herbs have been recognized for their valuable role in the treatment of diabetes worldwide and have been used empirically as antidiabetic and antihyperlipidemic remedies. Thus, phytotherapy involves the usage of herbal medications to treat the diseased individuals. It has been assessed that about 25 percentage of all recommended medicine today include ingredients derived from plants [7]. The pharmaceutical potential of plants has been well recognized in India as well. This wide acceptance of plants as medical sources accounts to the belief that natural products are safe. However, medicinal plants should be studied thoroughly to understand their properties, safety, and efficiency [8]. Seaweeds are marine macroscopic algae which form a significant constituent of marine organisms. They are divided into two groups, namely, microalgae and macroalgae or seaweed. The history of medicinal use of seaweeds in ancient China dates back to a period of 5000 years [9]. Seaweeds are also used as food supplements traditionally. Several epidemiological reports indicate that seaweeds have been used as medicine since time immemorial by several ethnic societies for the prevention and cure of chronic diseases $[10,11]$. This study was designed to establish the hypolipidemic potential of methanolic extract of Gracilaria corticata (MGC) on normal and STZinduced diabetic rats.

\section{METHODS}

Chemicals

STZ was purchased from Sigma-Aldrich, St. Louis, USA. All other chemicals used were of analytical grade, obtained from E. Merck Limited and HIMEDIA, Mumbai, India.

\section{Seaweed collection}

Seaweeds of Gracilaria corticata were collected during the month of June from sea coasts of Mandapam, Rameswaram, Tamil Nadu, India.

\section{Authentification of $G$. corticata seaweed}

The collected $G$. corticata seaweed was botanically identified by Dr. P. Anantharaman, Associate professor, Department of CAS Marine Biology, Annamalai University, Annamalainagar, Tamil Nadu, and voucher specimen deposited. 


\section{Preparation of extract}

G. corticata seaweed was cleaned and the necrotic parts were removed. The seaweeds were washed with tap water to remove any associated debris and shade dried at room temperature $\left(28 \pm 2^{\circ} \mathrm{C}\right)$ for $5-8$ days or until brittle. After complete drying, the seaweed materials were ground to a fine powder using electrical blender. $50 \mathrm{~g}$ of powdered G. corticata seaweeds was extracted with $200 \mathrm{~mL}$ of methanol using a soxhlet extractor. The extract was evaporated to dryness under reduced pressure using a rotary vacuum evaporator, yield calculated and stored in a refrigerator at $4^{\circ} \mathrm{C}$ for future use. The methanolic extract of Gracilaria corticata was duly abbreviated as MGC.

\section{Experimental animals}

Healthy adult male albino Wistar rats, bred and reared in Animal House, School of Pharmacy, Vels University, were used for the experiment. Weight matched animals (120-150 g) were selected and housed in polypropylene cages layered with husk and kept in a seminatural light/dark condition (12 hrs light/12 hrs dark). The animals were allowed free access to water and standard pellet diet (Amrut Laboratory Animal Feed, Pranav Agro Industries Ltd., Bengaluru, India). Animal handling and experimental procedures were approved by the Institutional Animal Ethics Committee, Vels University (CPCSEA Approval No. (XV/VELS/PCOL/11/2000/ CPCSEA/IAEC/30.10.2013).

\section{Induction of diabetes}

Overnight-fasted animals were induced with diabetes by a single intraperitoneal injection of STZ (Dose $-40 \mathrm{mg} / \mathrm{kg}$ b.w.t.) reconstituted in fresh citrate buffer $(0.1 \mathrm{M}, \mathrm{pH} 4.5)$. STZ injected animals were given $20 \%$ glucose solution for $24 \mathrm{hrs}$ to prevent initial druginduced hypoglycemic mortality. The induced animals exhibited massive glycosuria (determined by Benedict's qualitative test) and hyperglycemia (estimated by glucose oxidase method) within 4 days. Diabetes in STZ rats was confirmed by measuring the fasting blood glucose concentration, 96 hrs after injection with STZ by tail vein puncture. The animals with fasting blood glucose levels above $240 \mathrm{mg} / \mathrm{dL}$ were considered diabetic and used for subsequent experiments.

\section{Experimental design}

The animals were randomly divided into five groups of six animals each. Group I (Normal control) received only water. Group II consisted of normal rats treated with $100 \mathrm{mg} / \mathrm{kg}$ b.w.t of MGC. Group III were STZ-induced rats referred to as diabetic control. Group IV consisted of diabetic rats treated with $100 \mathrm{mg} / \mathrm{kg}$ b.w.t of MGC. Group V animals were diabetic rats treated with $600 \mu \mathrm{g} / \mathrm{kg}$ b.w.t of glibenclamide that served as standard drug control.

After 45 days, the animals were anesthetized using ketamine (24 mg/kg BW, intramuscular injection), and sacrificed by cervical dislocation. Blood was collected, tissue samples of liver, kidney and heart excised, processed and used for further biochemical estimations.

\section{Biochemical estimations}

Total cholesterol (TC) was estimated by the method described by Allain et al., 1974 [12]; Triglycerides (TG) by McGowan et al., 1983 [13]; Free fatty acids (FFA) by Falholt et al., 1973 [14]; phospholipids (PL) by Zilversmit and Davis, 1950 [15]; HDL-cholesterol by Izzo et al.1981 [16]; VLDL- and LDL-cholesterol by Friedewald et al., 1972 [17].

\section{Statistical analysis}

Data were expressed as mean \pm SD for control and experimental animals. The data were analyzed using one-way analysis of variance on SPSS/PC, Ver. 10 and the group means were compared by Duncan's multiple range test.

\section{RESULTS AND DISCUSSION}

Type II diabetes mellitus, the most prevalent form is characterized by a combination of defective insulin secretion and insulin resistance [1].
Insulin resistance usually paves way for the onset of type II diabetes which is accompanied by cardiovascular risk factors such as dyslipidemia, hypertension followed by heart failures. This study analyzed the hypolipidemic effect of methanolic $G$. corticata extract in STZ-induced type II diabetic rats.

Levels of TC, TG, FFA, and phospholipids in the plasma, liver, kidney, and heart of diabetic rats are represented in Tables 1-4, respectively. The diabetic rats showed a significant increase in the levels of TC, TG, phospholipids and FFA while treatment with MGC decreased these indices significantly $(\mathrm{p}<0.05)$ comparable to the effects of standard drug glibenclamide.

Deficiency or insufficiency of insulin renders DM patients susceptible to lipid profile abnormalities mainly because of the derangements in the regulation of lipid metabolism, thereby making them more prone to hypercholesterolemia and hypertriglyceridemia [18]. Earlier studies have also reported these lipid metabolic derangements in STZ-induced rat models $[19,20]$.

The hyperlipidemic manifestation of diabetes mellitus is usually treated through administration of lipid-lowering drugs, consumption of low-fat diet apart from improving glycemic control and by increasing physical exercises [21]. The treatment of dyslipidemia with lipid-lowering drugs may be associated with serious adverse side effects. Hence, the hypolipidemic effects of dietary components are presently receiving considerable attention, highlighting the importance of natural products as therapeutics [22]. It has been established that dietary/drug therapy reduces the risk of cardiovascular diseases by lowering the plasma lipid levels [23]. Administration of MGC to diabetic rats also decreased the levels of cholesterol significantly $(\mathrm{p}<0.05)$.

Diseases in which prolonged elevated levels of VLDL, IDL, chylomicron remnants, or LDL occur in the blood (e.g., diabetes mellitus, lipid nephrosis, hypothyroidism, and other conditions of hyperlipidemia) are often accompanied by premature or severe atherosclerosis. There is also an inverse relationship between HDL concentrations and coronary heart disease, and some consider that the most predictive relationship is the LDL: HDL cholesterol ratio [24].

In this study too, the diabetic rats had elevated levels of LDL-C and VLDL-C, and decreased level of HDL-C, while treatment with MGC improved these values significantly $(\mathrm{p}<0.05)$ as observed in Table 5 . The values were almost identical to that of the diabetic rats that were treated with glibenclamide, the reference drug. These evidences are suggestive of the protective action of MGC with respect to the lipid metabolism parameters in Type II diabetes mellitus. Thus, our findings show that MGC does have an antihyperlipidemic effect, which is evidenced by the decreased levels of TC, TG, LDL-C, VLDL-C, FFA and PL, and elevated level of HDL-C in the treated rats. Phytocomponents educe a wide range of biological activities which include hypoglycemia, hypolipidemia, etc., [25]. For instance, literature reveals that Swathi R Dhande et al. [26] have established the antihyperlipidemic activity of methanolic extract of Bambusa bambos and ethanolic extract of Swertia chirata and the results indicated significant decreases in serum TC, TG, LDL-C and VLDL-C levels, and increased serum HDL-C level. In another study, Cinnamomum iners leaves when administrated to diabetic rats for 12 days also increased HDL level and decreased the TC, TG, LDL, and VLDL levels [27].

Saponins are known to reduce serum cholesterol levels by causing resin-like action, thereby reducing the enterohepatic circulation of bile acids [28], thus increasing the conversion of cholesterol to bile acids resulting in low cholesterol levels $[29,30]$. Seaweeds are known to contain several inorganic and organic bioactive compounds such as polyphenols and tocopherols which prove to be advantageous to human health and are regarded as a potential source for the development of novel pharmaceutical agents [31]. They are also great sources of a wide variety of secondary metabolites categorized by a 
Table 1: Effect of MGC on total cholesterol in plasma and tissues of STZ diabetic rats

\begin{tabular}{|c|c|c|c|c|}
\hline Groups & Plasma (mg/dl) & Liver (mg/g tissue) & Kidney (mg/g tissue) & Heart (mg/g tissue) \\
\hline Control & $80.17 \pm 3.92^{\mathrm{a}}$ & $3.62 \pm 0.31^{\mathrm{a}}$ & $4.75 \pm 0.29^{\mathrm{a}}$ & $2.10 \pm 0.19^{\mathrm{a}}$ \\
\hline Control+MGC (100 mg/kg BW) & $75.56 \pm 3.25^{\mathrm{a}}$ & $3.41 \pm 0.25^{\mathrm{a}}$ & $4.14 \pm 0.46^{\mathrm{a}}$ & $2.24 \pm 0.10^{\mathrm{a}}$ \\
\hline Diabetic control & $158.04 \pm 10.73^{b}$ & $5.94 \pm 0.53^{b}$ & $8.53 \pm 0.34^{b}$ & $4.77 \pm 0.34^{b}$ \\
\hline Diabetic+MGC (100 mg/kg BW) & $97.49 \pm 5.34^{c}$ & $4.47 \pm 0.27^{c}$ & $6.1 \pm 0.47^{c}$ & $3.12 \pm 0.19^{c}$ \\
\hline Diabetic+glibenclamide $(600 \mu \mathrm{g} / \mathrm{kg} \mathrm{BW})$ & $86.32 \pm 3.60^{d}$ & $4.04 \pm 0.17^{\mathrm{d}}$ & $5.27 \pm 0.24^{\mathrm{d}}$ & $2.71 \pm 0.17^{\mathrm{d}}$ \\
\hline
\end{tabular}

MGC: Methanolic extract of Gracilaria corticata, STZ: Streptozotocin, DMRT: Duncan's multiple range test. Values are given as mean \pm standard deviation for six rats in each group, values not sharing a common superscript differ significantly at $\mathrm{p} \leq 0.05$ (DMRT)

Table 2: Effect of MGC on triglycerides in plasma and tissues of STZ diabetic rats

\begin{tabular}{|c|c|c|c|c|}
\hline Groups & Plasma (mg/dL) & Liver (mg/g tissue) & Kidney (mg/g tissue) & Heart (mg/g tissue) \\
\hline Control & $51.64 \pm 3.72^{\mathrm{a}}$ & $3.51 \pm 0.21^{\mathrm{a}}$ & $4.68 \pm 0.34^{\mathrm{a}}$ & $3.82 \pm 0.27^{\mathrm{a}}$ \\
\hline Control+MGC (100 mg/kg BW) & $49.33 \pm 2.81^{\mathrm{a}}$ & $3.49 \pm 0.28^{\mathrm{a}}$ & $4.39 \pm 0.30^{\mathrm{a}}$ & $3.55 \pm 0.21^{\mathrm{a}}$ \\
\hline Diabetic control & $143.17 \pm 11.45^{b}$ & $7.32 \pm 0.57^{\mathrm{b}}$ & $6.89 \pm 0.52^{\mathrm{b}}$ & $6.21 \pm 0.42^{\mathrm{b}}$ \\
\hline Diabetic+MGC (100 mg/kg BW) & $70.24 \pm 5.45^{c}$ & $4.85 \pm 0.36^{c}$ & $5.33 \pm 0.39^{c}$ & $4.87 \pm 0.28^{c}$ \\
\hline Diabetic+glibenclamide $(600 \mu \mathrm{g} / \mathrm{kg} \mathrm{BW})$ & $61.40 \pm 4.97^{\mathrm{d}}$ & $4.29 \pm 0.24^{\mathrm{d}}$ & $4.85 \pm 0.41^{\mathrm{a}}$ & $4.35 \pm 0.30^{\mathrm{d}}$ \\
\hline
\end{tabular}

MGC: Methanolic extract of Gracilaria corticata, STZ: Streptozotocin, DMRT: Duncan's multiple range test. Values are given as mean \pm standard deviation for six rats in each group, values not sharing a common superscript differ significantly at $\mathrm{p} \leq 0.05$ (DMRT)

Table 3: Effect of MGC on free fatty acids in plasma and tissues of STZ diabetic rats

\begin{tabular}{lllll}
\hline Groups & Plasma (mg/dL) & Liver (mg/g tissue) & Kidney (mg/g tissue) & Heart (mg/g tissue) \\
\hline Control & $62.84 \pm 4.72^{\mathrm{a}}$ & $7.32 \pm 0.42^{\mathrm{a}}$ & $5.39 \pm 0.25^{\mathrm{a}}$ & $6.38 \pm 0.34^{\mathrm{a}}$ \\
Control+MGC (100 mg/kg BW) & $59.73 \pm 3.19^{\mathrm{a}}$ & $7.09 \pm 0.51^{\mathrm{a}}$ & $5.23 \pm 0.62^{\mathrm{a}}$ & $6.31 \pm 0.57^{\mathrm{a}}$ \\
Diabetic control & $117.37 \pm 8.34^{\mathrm{b}}$ & $15.19 \pm 0.67^{\mathrm{b}}$ & $9.60 \pm 0.59^{\mathrm{b}}$ & $11.34 \pm 1.18^{\mathrm{b}}$ \\
Diabetic+MGC (100 mg/kg BW) & $81.22 \pm 5.70^{\mathrm{c}}$ & $9.76 \pm 0.49^{\mathrm{c}}$ & $6.56 \pm 0.64^{\mathrm{c}}$ & $8.10 \pm 0.56^{\mathrm{c}}$ \\
Diabetic+glibenclamide (600 $\mu \mathrm{gg} / \mathrm{kg} \mathrm{BW)}$ & $72.12 \pm 5.48^{\mathrm{d}}$ & $8.90 \pm 0.62^{\mathrm{d}}$ & $5.14 \pm 0.33^{\mathrm{a}}$ & $7.18 \pm 0.45^{\mathrm{d}}$ \\
\hline
\end{tabular}

MGC: Methanolic extract of Gracilaria corticata, STZ: Streptozotocin, DMRT: Duncan's multiple range test, Values are given as mean \pm standard deviation for six rats in each group, values not sharing a common superscript differ significantly at $\mathrm{p} \leq 0.05$ (DMRT)

Table 4: Effect of MGC on phospholipids in plasma and tissues of STZ-diabetic rats

\begin{tabular}{|c|c|c|c|c|}
\hline Groups & Plasma (mg/dL) & Liver (mg/g tissue) & Kidney (mg/g tissue) & Heart (mg/g tissue) \\
\hline Control & $79.32 \pm 4.47^{\mathrm{a}}$ & $20.64 \pm 1.43^{\mathrm{a}}$ & $15.43 \pm 1.14^{\mathrm{a}}$ & $11.34 \pm 0.57^{\mathrm{a}}$ \\
\hline Control+MGC (100 mg/kg BW) & $80.83 \pm 6.53^{a}$ & $20.84 \pm 1.65^{a}$ & $14.19 \pm 1.23^{\mathrm{a}}$ & $11.03 \pm 0.52^{\mathrm{a}}$ \\
\hline Diabetic control & $132.64 \pm 9.13^{b}$ & $51.72 \pm 3.94^{\mathrm{b}}$ & $33.29 \pm 2.84^{\mathrm{b}}$ & $25.17 \pm 1.72^{\mathrm{b}}$ \\
\hline Diabetic+MGC (100 mg/kg BW) & $96.51 \pm 5.28^{\mathrm{c}}$ & $31.85 \pm 2.27^{c}$ & $22.02 \pm 1.92^{\mathrm{c}}$ & $16.33 \pm 1.20^{c}$ \\
\hline Diabetic+glibenclamide $(600 \mu \mathrm{g} / \mathrm{kg} \mathrm{BW})$ & $85.94 \pm 4.60^{\mathrm{d}}$ & $26.90 \pm 0.92^{\mathrm{d}}$ & $16.28 \pm 0.70^{\mathrm{a}}$ & $12.28 \pm 0.90^{\mathrm{a}}$ \\
\hline
\end{tabular}

MGC: Methanolic extract of Gracilaria corticata, STZ: Streptozotocin, DMRT: Duncan's multiple range test, Values are given as mean \pm standard deviation for six rats in each group, values not sharing a common superscript differ significantly at $\mathrm{p} \leq 0.05$ (DMRT)

Table 5: Effect of MGC on lipoprotein profile in the plasma of STZ diabetic rats

\begin{tabular}{llll}
\hline Groups & HDL (mg/dL) & VLDL (mg/dL) & LDL (mg/dL) \\
\hline Control & $47.53 \pm 3.24^{\mathrm{a}}$ & $10.32 \pm 0.42^{\mathrm{a}}$ & $22.31 \pm 0.30^{\mathrm{a}}$ \\
Control+MGC $(100 \mathrm{mg} / \mathrm{kg} \mathrm{BW)}$ & $45.19 \pm 2.47^{\mathrm{a}}$ & $9.86 \pm 0.46^{\mathrm{a}}$ & $23.54 \pm 0.49^{\mathrm{a}}$ \\
Diabetic control & $28.98 \pm 1.31^{\mathrm{b}}$ & $31.43 \pm 1.31^{\mathrm{b}}$ & $86.11 \pm 3.13^{\mathrm{b}}$ \\
Diabetic+MGC $(100 \mathrm{mg} / \mathrm{kg} \mathrm{BW})$ & $40.03 \pm 2.29^{\mathrm{c}}$ & $16.48 \pm 0.69^{\mathrm{c}}$ & $36.96 \pm 1.15^{\mathrm{c}}$ \\
Diabetic+glibenclamide $(600 \mu \mathrm{kg} / \mathrm{kg})$ & $42.26 \pm 3.08^{\mathrm{c}}$ & $14.88 \pm 0.54^{\mathrm{c}}$ & $31.98 \pm 0.53^{\mathrm{d}}$ \\
\hline
\end{tabular}

MGC: Methanolic extract of Gracilaria corticata, STZ: Streptozotocin, HDL: High-density lipoprotein, VLDL: Very low-density lipoprotein, LDL: Low-density lipoprotein, DMRT: Duncan's multiple range test. Values are given as mean \pm standard deviation for six rats in each group, values not sharing a common superscript differ significantly at $\mathrm{p} \leq 0.05$ (DMRT)

wide-ranging spectrum of biological activities [32]. Phytochemical analysis of seaweeds revealed the presence of secondary metabolites such as steroids, phenolic groups, saponins, tannins, flavonoids, carbohydrates, coumarins and xanthoproteins [33]. They synthesize a diverse range of unique secondary metabolites that have not been reported in terrestrial plants. The antioxidant potential of numerous edible seaweeds was found to be remarkably high [34]. Cardioprotective roles of red, brown, and green algae have also been established recently [35]. Subashini et al. [36] have earlier proved the antihyperglycemic effect of different extracts of $G$. corticata in STZ-induced diabetic and normal rats. The most usually observed lipid abnormalities in diabetes are hypercholesterolemia and hypertriglyceridemia $[37,38]$ and these contribute to coronary artery disease [39].

Lipid abnormalities associated with atherosclerosis is the major cause of cardiovascular disease in diabetes. The treatment of diabetes, therefore, should have a favorable effect on lipid profiles in addition to glycemic control. Thus, seaweeds may serve as excellent alternative medicinal sources that aid the prevention of long-term complications such as atherosclerosis and heart diseases by exerting hypolipidemic and cardioprotective roles. 


\section{CONCLUSION}

In conclusion, the results of this study ascertain the hypolipidemic potential of MGC in STZ-induced diabetic rats. However, further investigations are required to elucidate the detailed mechanism of action of the extract that brings forth its antihyperlipidemic effect.

\section{REFERENCES}

1. American Diabetes Association. Diagnosis and classification of diabetes mellitus. Diabetes Care 2012;30:S42-7.

2. Shaw JE, Sicree RA, Zimmet PZ. Global estimates of the prevalence of diabetes for 2010 and 2030. Diabetes Res Clin Pract 2010;87(1):4-14.

3. Szkudelski T. The mechanism of alloxan and streptozotocin action in B cells of the rat pancreas. Physiol Res 2001;50(6):537-46.

4. Sushma N, Smitha PV, Gopal YV, Vinay R, Reddy NS, Mohan CM, et al. Antidiabetic, antihyperlipidemic and antioxidant activities of Buchanania lanzan Spreng methanol leaf extract in streptozotocininduced Types I and II diabetic rats. Trop J Pharm Res 2013;12(2):221-6.

5. Kameswara Rao B, Giri R, Kesavulu MM, Apparao C. Effect of oral administration of bark extracts of Pterocarpus santalinus L. On blood glucose level in experimental animals. J Ethnopharmacol 2001;74(1):69-74.

6. Betteridge DJ. Diabetic dyslipidemia. Am J Med 1994;96(6A):25S-31.

7. Najafi S, Deokule SS. Pharmacognostic study of Tylophora dalzellii Hook. f. J Med Plants Res 2010;4(5):403-6.

8. Eloff JN. Which extractant should be used for the screening and isolation of antimicrobial components from plants? J Ethnopharmacol 1998;60(1):1-8.

9. Namvar F, Mohamad R, Baharara J, Zafar-Balanejad S, Fargahi F, Rahman HS. Antioxidant, antiproliferative, and antiangiogenesis effects of polyphenol-rich seaweed (Sargassum muticum). Biomed Res Int 2013;2013:1-9.

10. Southgate DA, Waldron K, Johnsons IT, Fenwick GR. Dietary Fiber and Health: Chemical Biological Aspects. London: Royal; 1990. p. 10-9.

11. Ribeiro LR, Salvadori DM. Dietary components may prevent mutationrelated diseases in humans. Mutat Res 2003;544(2-3):195-201.

12. Allain CC, Poon LS, Chan CS, Richmond W, Fu PC. Enzymatic determination of total serum cholesterol. Clin Chem 1974;20(4):470-5.

13. McGowan MW, Artiss JD, Strandbergh DR, Zak B. A peroxidasecoupled method for the colorimetric determination of serum triglycerides. Clin Chem 1983;29(3):538-42.

14. Falholt K, Lund B, Falholt W. An easy colorimetric micromethod for routine determination of free fatty acids in plasma. Clin Chim Acta 1973;46(2):105-11.

15. Zilversmit DB, Davis AK. Microdetermination of plasma phospholipids by trichloroacetic acid precipitation. J Lab Clin Med 1950;35(1):155-60.

16. Izzo C, Grillo F, Murador E. Improved method for the determination of high density lipoprotein cholesterol, I. Isolation of high-density lipoproteins by the use of polyethylene glycol 6000. Clin Chem 1981;27(3):371-4.

17. Friedewald WT, Levy RI, Fredrickson DS. Estimation of the concentration of low-density lipoprotein cholesterol in plasma, without use of the preparative ultracentrifuge. Clin Chem 1972;18(6):499-502.

18. Fontbonne A, Eschwège E, Cambien F, Richard JL, Ducimetière P, Thibult $\mathrm{N}$, et al. Hypertriglyceridaemia as a risk factor of coronary heart disease mortality in subjects with impaired glucose tolerance or diabetes. Results from the 11-year follow-up of the Paris Prospective Study. Diabetologia 1989;32(5):300-4.

19. Motta M, Giugno I, Bosco S, Pistone G, Ruello P, Maugeri D, et al. Serum lipoprotein(a) changes in acute myocardial infarction. Panminerva Med 2001;43(2):77-80.

20. Nesto RW. Beyond low-density lipoprotein: Addressing the atherogenic lipid triad in Type 2 diabetes mellitus and the metabolic syndrome.
Am J Cardiovasc Drugs 2005;5(6):379-87.

21. Blevins T. Therapeutic options that provide glycemic control and weight loss for patients with Type 2 diabetes. Postgrad Med 2010;122(1):172-83.

22. Marinangeli CP, Varady KA, Jones PJ. Plant sterols combined with exercise for the treatment of hypercholesterolemia: Overview of independent and synergistic mechanisms of action. J Nutr Biochem 2006;17(4):217-24.

23. Grundy SM, Benjamin IJ, Burke GL, Chait A, Eckel RH, Howard BV, et al. Diabetes and cardiovascular disease: A statement for healthcare professionals from the American Heart Association. Circulation 1999;100(10):1134-46.

24. Peter MA, Kathleen BM. Cholesterol synthesis, transport and excretion. In: Murray RK, Bender DA, Botham KM, Kennelly PJ, Rodwell VW, Anthony WP, editors. Harper's Illustrated Biochemistry. $28^{\text {th }}$ ed. Lange: McGraw-Hill; 2009.

25. Oladele SB, Ayo JO, Adaudi AO. Medicinal and physiological properties of flavonoids, coumarin derivatives and anthraquinones of plant origin. West Afr J Pharmacol Drug Res 1995;11:134-44.

26. Dhande SR, Kaikini AA, Patil KA, Kadam V. Antihyperlipidemic activity of Bambusa Bambos (Druce.) And Swertia chirata (BuchHam) in cholesterol suspension induced hypercholesterolemia in rats. Int J Pharm Pharm Sci 2014;6(1):607-10.

27. Mustaffa F, Hassan Z, Yusof NA, Razak KN, Asmawi MZ. Antidiabetic and antihyperlipidemic potential of standardized extract, fraction and subfraction of Cinnamomum iners leaves. Int J Pharm Pharm Sci 2014;6(1):220-5

28. Topping DL, Storer GB, Calvert GD, Illman RJ, Oakenfull DG, Weller RA. Effects of dietary saponins on fecal bile acids and neutral sterols, plasma lipids and lipoprotein turnover in the pig. Am J Clin Nutr 1980;33(4):783-6.

29. Kritchevsky D. Dietary fiber and other dietary factors in hypercholesterema. Am J Clin Nutr 1977;30(6):979-84.

30. Potter JD, Topping DL, Oakenfull D. Soya, saponins, and plasmacholesterol. Lancet 1979;1(8109):223.

31. Chanda S, Dave R, Kaneria M, Nagani K. Seaweeds: A novel, untapped source of drugs from sea to combat infectious diseases. Current Research, Technology and Education Topics in Applied. Microbial Biotechnology. Badajoz, Spain: Formatex Research Center; 2010. p. $473-80$

32. Rajasulochana P, Dhamotharan R, Krishnamoorthy P, Murugesan S. Antibacterial activity of the extracts of marine red and brown algae. J Am Sci 2009;5(3):20-5.

33. Jeeva S, Antonisamy MJ, Domettila C, Anantham B, Mahesh M. Preliminary phytochemical studies on some selected seaweeds from Gulf of Mannar, India. Asian Pac J Trop Biomed 2012;S30-3.

34. Cofrades S, López-López I, Bravo L, Ruiz-Capillas C, Bastida S, Larrea MT, et al. Nutritional and antioxidant properties of different brown and red Spanish edible seaweeds. Food Sci Technol Int 2010;16(5):361-70.

35. Matanjun P, Mohamed S, Muhammad K, Mustapha NM. Comparison of cardiovascular protective effects of tropical seaweeds, Kappaphycus alvarezii, Caulerpa lentillifera, and Sargassum polycystum, on high-cholesterol/high-fat diet in rats. J Med Food 2010;13(4):792-800

36. Subashini S, Pugalendi KV, Baskaran K, Kripa KG. Anti-hyperglycaemic effect of Gracilaria corticata extracts on STZ-induced diabetic rats. Chem Biol Lett 2015;2(1):6-11.

37. Arvind K, Pradeepa R, Deepa R, Mohan V. Diabetes \& coronary artery disease. Indian J Med Res 2002;116:163-76.

38. Shepherd J. Does statin monotherapy address the multiple lipid abnormalities in Type 2 diabetes? Atheroscler Suppl 2005;6(3):15-9

39. Shirwaikar A, Rajendran K, Barik R. Effect of aqueous bark extract of Garuga pinnata Roxb. In streptozotocin-nicotinamide induced Type-II diabetes mellitus. J Ethnopharmacol 2006;107(2):285-90. 